\title{
Molecular Characterization of a Jatropha leaf curl virus (JLCuV) Infecting a New Host Ludwigia parviflora in India
}

\author{
Buddhadeb Roy, Siriya Sultana and Ang Rinzing Sherpa*
}

Department of Botany, West Bengal State University, Malikapur, Berunanpukuria, 24 North Parganas, Barasat, Kolkata, 700126 (W.B.), India

*Corresponding author

\section{A B S T R A C T}

\section{Keywords}

Begomovirus, PCR, Southern blot, Detection, Ludwigia, India.

\section{Article Info}

Accepted:

04 April 2017 Available Online:

10 May 2017
During survey from March 2014 to October 2015, in Barasat, West Bengal, India, incidence of symptoms including leaf curling, leaf yellowing and stunted growth suggestive of virus infection was observed in Ludwigia parviflora and Jatropha gossipiifolia. The occurrence of Jatropha leaf curl virus (JLCuV) was confirmed by symptomatology, southern blot analysis, polymerase chain reaction (PCR) and sequence analysis of the whole genome. Host range study was done in Capsicum annuum and further the transmission of the virus was confirmed by PCR. Partial sequences from $L$. parviflora and J. gossipiifolia showed that the virus from both the plants shares $89 \%$ with Jatropha leaf curl virus (JLCuV) and $88 \%$ with Jatropha mosaic Indian virus (JMIV) at nucleotide level. The sequence identity between viruses from the two plants shares $99 \%$ at nucleotide level. Further, the whole genome sequence analysis showed that the virus from L. parviflora share $95 \%$ identity with other available sequences of Jatropha leaf curl virus $(\mathrm{JLCuV})$ isolates and shares $77 \%-82 \%$ identity with other begomoviruses at nucleotide level. This is the first molecular evidence of Jatropha leaf curl virus infecting Ludwigia parviflora in West Bengal, India.

\section{Introduction}

Jatropha leaf curl virus (JLCuV) is a member of whitefly-transmitted geminiviruses of the genus begomovirus. It is a single stranded DNA virus and is important pathogen of a wide range of crop ecosystems reported from the different parts of India. Jatropha, a genus of perennial flowering plants under the family Euphorbiaceae, is native to Central America and distributed in Africa and Asia (Speight and Singh, 2014). The species under the Genus Jatropha are Jatropha curcas, J. gossypifolia, J. podagrica, J. integerrima, J. multifida and $J$. curcas is widely cultivated as a major source of bio-fuel (Openshaw, 2000;
Pramanik, 2003) while J. gossypifolia grows as a weed in field and along road sides (Snehi et al., 2011). The species J. integerrima, J. podagrica and J. multifida are grown as ornamental plants in Indian gardens. $J$. integerrima is cultivated as an ornamental shrub that grows commonly in southern parts of India (Sharma and Singh, 2013).

In India the area under the cultivation of Jatropha is increasing in recent years. Jatropha suffers from different fungal and bacterial diseases and more recently by the Jatropha leaf curl virus (JLCuV) and 
Jatropha mosaic Indian virus (JMIV), which causes Jatropha mosaic disease (JMD). JMD was first reported from Karnataka state, South India in 2004 and are shown to be associated with a begomovirus based on the whitefly Bemisia tabaci (Gennadius) transmission tests of the virus and virus detection by polymerase chain reaction (PCR) (Aswatha Narayana et al., 2007). However, the nature of the virus was not fully known and its phylogenetic relationship with other begomoviruses was not established.

Weed species are believed to act as reservoir hosts for many economically important plant virus diseases. Ludwigia parviflora is a commonly and frequently occurring weed species in northern India. They are found widely distributed in cultivated and uncultivated land, wasteland, railway tracks, and road sides. During survey of begomovirus infection Jatropha gossypiifolia and Ludwigia parviflora showing prominent symptoms of begomovirus infection, such as yellow vein (vein yellowing) and yellow mosaic on leaves accompanied with marginal leaf curling, swelling of veins, with a bushy appearance of the plants were collected (Figure 1).

\section{Materials and Methods}

For the identification of the begomovirus the symptomatic leaf of $L$. parviflora and $J$. gossypiifolia were collected from the Barasat, West Bengal in India and stored in $-80{ }^{\circ} \mathrm{C}$ for future investigation.

For the detection of begomovirus, two detection techniques were used: 1) PCR amplification of virus by using indigenously designed geminivirus specific primer pair and 2) using Southern blot analysis using biotinlabeled probes specific for geminivirus.

Total DNA was extracted from the symptomatic leaves using CTAB method
(Ghosh et al., 2009), tested for the presence of geminiviruses by PCR using indigenously designed geminiviruses specific degenerate primer pair (Roy et al., 2015).

For the Southern blot analysis we designed a biotin labeled probe and used for the detection of the geminiviruses from the total sap of the infected plant samples. Briefly, about $5 \mu \mathrm{l}$ of freshly prepared sap was blotted on the nitro cellulose membrane and air dried the membrane properly. After that the membrane was UV-cross linked for $30 \mathrm{~min}$ under UVCross Linker (GeNei ${ }^{\mathrm{TM}}$ India). Prehybridization, hybridization and washing of membrane were done according to the southern blot analysis protocol using biotinlabeled probes (Weigel et al., 2015).

The complete viral genome from $L$. parviflora was amplified by Rolling Circle Amplification (RCA) using the Illustra Templiphi DNA Amplification Kit (GE Healthcare, USA) as per manufacturer's instructions, cloned into pUC19 plasmid. The plasmids were isolated by plasmid isolation kit and sent for sequencing with different sets of primers covering whole genome of the virus. The whole genome sequence was aligned with available begomovirus DNA-A sequences obtained from the GenBank database using Multalin, MUSCLE, BLASTn, and pairwise identity scores were calculated using SDTv1.2 (Sequences Demarcation Tool version 1.2). Phylogenetic tree was constructed using the neighbor-joining (NJ) method of PHYLIP.

Cultures of Jatropha leaf curl virus (JLCuV) (an isolate from Barasat) were maintained in healthy $L$. parviflora plants in laboratory condition. The mechanical transmission was conducted with sap inoculation. Briefly, the infected L. parviflora leaves were crushed in $0.1 \mathrm{M}$ potassium phosphate buffer, $\mathrm{pH} 7.0$ $(1: 2, \mathrm{w} / \mathrm{v})$ containing $0.15 \%$ sodium sulphite. 
The sap from infected plant was used to inoculate the healthy $L$. parviflora with the help of carborundum powder (Chakraborty et al., 2003). Five different plants were selected for transmission test. Initially, the young leaves of test plants were dusted with carborundum powder, then a cotton-wrapped stick was soaked in the sap inoculum. The stick was rubbed on the leaves gently where carborundum powder was previously applied. Inoculated plants were kept in a net house for symptom development. The visible symptoms appeared after transmission experiment confirmed the success mechanical transmission of the virus.

For monitoring of JLCuV in Chilli plants (Capsicum annuum), healthy B. tabaci were fed on infected leaves of L. parviflora for 24 hours. After acquisition access period, viruliferous $B$. tobaci were collected and a batch of ten insect per plant was placed on healthy seedling of $C$. annuum for an additional 24 hours.

Two kinds of experiments were conducted. In the first experiment, observations were relied upon the appearance of symptoms in mechanically inoculated $L$. parviflora plants. In the second experiment, monitoring of virus was based on PCR amplification. To accomplish this, leaf samples were taken at $10,12,14,16,18,20$ and 22 days post inoculation (dpi) with viruliferous $B$. tabaci. Total DNA from JLCuV infected leaf samples was isolated and subjected to PCR.

\section{Results and Discussion}

Positive PCR reaction from L. parviflora and $J$. gossipiifolia indicates the begomovirus infection in the plants which amplified the parts of AV1, AC3 and AC2 genes fragment of approx $\sim 760$ bp in length from symptomatic plants, but were absence in symptomless samples (Figure 2a). PCR products were suitably cloned into pGEM-T vector and sequenced, and submitted in the GenBank database as accession number; LC010943 and LC010944 respectively. The sequences of the PCR products showed sequence identities of $89 \%$ with Jatropha leaf curl virus and $88 \%$ with Jatropha mosaic India virus at nucleotide level. Further comparison of the isolate with other begomoviruses showed sequence identity of below than $88 \%$ and they shares $99 \%$ with each other.

In Southern hybridization technique all samples from symptomatic plants hybridized with the probe, whereas samples extracted from non - symptomatic plants did not show positive results (Figure 2b). Hybridization of begomovirus probe with the DNA samples on the nitrocellulose membrane indicates that these probes can also be used for the detection of begomoviruses. The strong signal showed that the virus titer in L. parviflora is high.

The whole genome of the virus from $L$. parviflora was sequenced and analysis showed that the virus shares $95 \%$ identity with that of a JLCuV isolate from Gujarat (Acc.No.-GU451249) and shares $77 \%-82 \%$ identity with other begomoviruses at nucleotide level. The whole genome sequence of the virus infecting $L$. parviflora was submitted in GenBank as accession No. LCO80676. Phylogenetic tree was constructed using Vector NTI, BioEdit and Neighbor- joining analysis with Phylip programs, Banana bunchy top virus acc. No: EU140341 was used as an outgroup and marked with solid square. Our sequence was marked with solid triangle (Figure 3). 
Figure.1 Symptomatic L. parviflora plant showing yellow mosaic on leaves accompanied with marginal leaf curling, bushy appearance of the plants typical to that of begomovirus infection

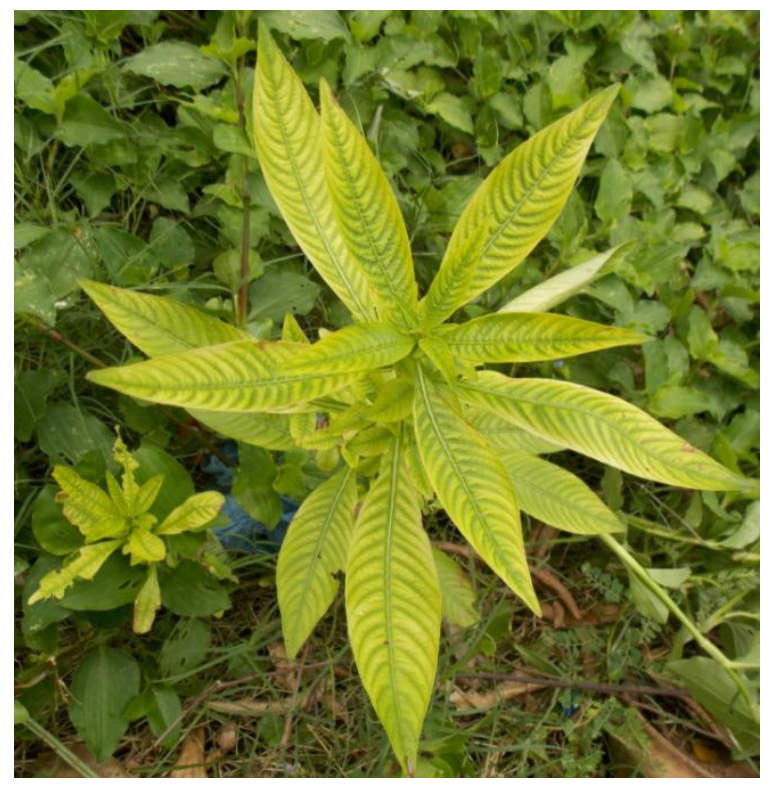

Figure.2 (a) PCR amplification of JLCuV containing AV1, AC3, AC2 gene fragment of about 760 bp from nucleic acid extracted from JLCuV infected leaves of L. parviflora (lane-1), J. gossipiifolia (lane 2) and Lane M: 100bp DNA Marker (3B BlackBio Biotech, India). (b) Southern hybridization detection of JLCuV by using biotin probe (lane 1, lane 2 and lane 3 were positive in Southern hybridization and lane 4 and lane 5 were found negative)

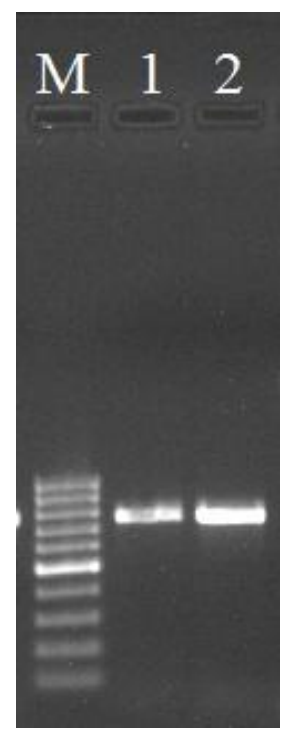

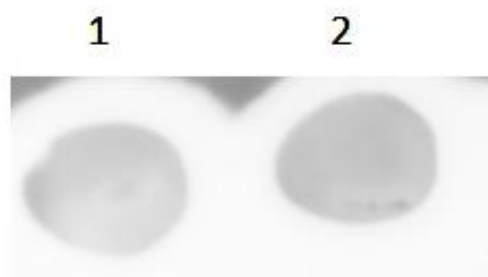

Figure 2a

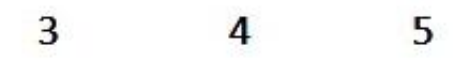

Figure 2b 
Figure.3 Phylogenetic trees reconstructed by the neighbour-joining method from the alignment of the full-genome nucleic acid sequence of JLCuV (acc. No. LCO80676) of the virus isolated from L. parviflora and other begomovirus sequences available in GenBank. Banana bunchy top virus acc. No: EU140341 was used as an outgroup and marked with solid square. Our sequence was marked with solid triangle. Host, country, accession numbers and virus names are given at the end of the branch

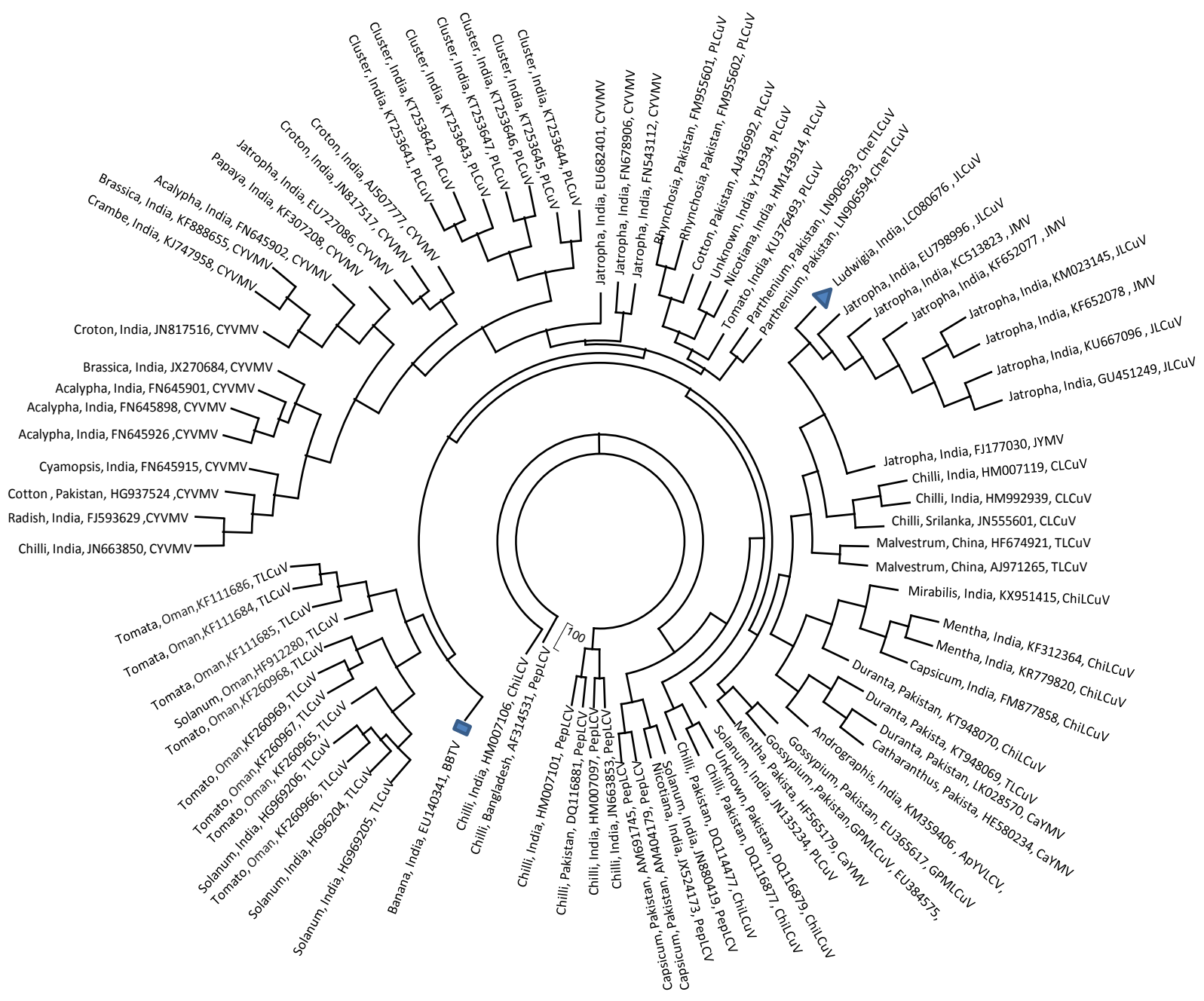

Figure.4 Detection of JLCuV DNA in L. parviflora inoculated with JLCuV. Total DNA was isolated from JLCuV infected leaf tissues and subjected to PCR. The PCR products were run in 1 $\%$ agarose gel containing ethidium bromide

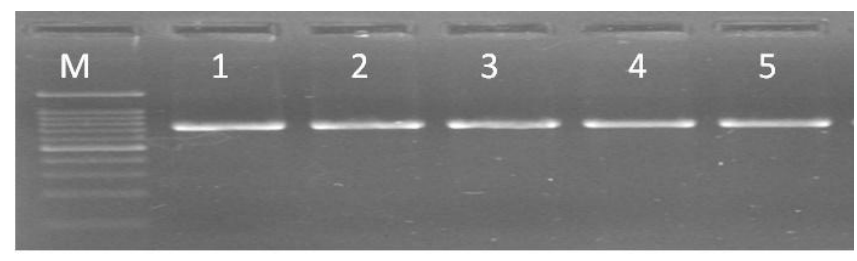


Figure.5 Detection of JLCuV DNA in C. апnиum plant at various dpi (days post inoculation) with mechanical inoculation of JLCuV., Total DNA was isolated from JLCuV inoculated leaf tissues of $C$. annuum plant at 10, 12, 14, 16, 18, 20 and 22 dpi (Lane 2- lane 8 respectively) and subjected to PCR. The PCR products were run in agarose gel containing ethidium bromide. JLCuV was not detected at 10, 12 and 14 dpi (lane:1-3 respectively) and detectable at 16,18, 20, 22 dpi (lane:4-7)

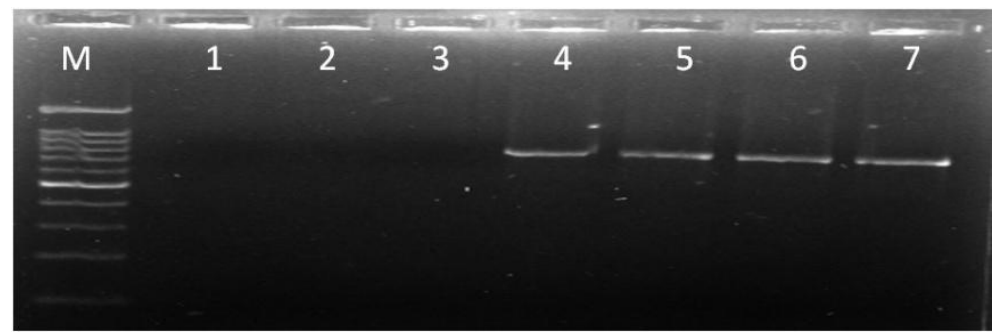

The characteristic symptoms were observed on L. parviflora 10-15 days after mechanical inoculation of the virus. The virus was found to be transmitted by mechanical transmission at transmission efficiency of $100 \%$. A positive PCR amplification of $760 \mathrm{bp}$ sized products was obtained with the DNA-A specific primer sets. Sequencing results confirmed the JLCuV infection (Figure 4). Similarly Jatropha leaf curl virus (JLCuV) from L. parviflora was successfully transmitted to chilli plant by $B$. tabaci in a varied period of incubation. The initial symptom was as curling of leaves with clearing and thickening of veins and height of the entire plant remains stunted. The JLCuV DNA was detects after 16 d.p.i. from inoculated chilli plant (Figure 5).

Our result also confirms that the virus infects L. parviflora and $J$ gossipiifolia in Barasat, India indicating potential threat to other cultivated crops. However, there is a need for more detailed study about JLCuV as it is broadening its host range. Many geminiviruses are already reported as emerging and re-emerging in the recent years and infecting different host and threatening the economically important crops which are susceptible for geminiviruses and therefore it is essential to study the survey and detection of the viruses in other crops, spread of the disease and characterize the viruses in detail at molecular level. The study of molecular interaction between the host and vectors of the viruses, explorations into the ecology of these viruses, including interactions with other viruses are also important areas to focus in future research. To the best of our knowledge this is the first record of $L$. parviflora as a natural host of JLCuV.

\section{Acknowledgement}

Authors would like to thank Department of Science and Technology, New Delhi for SERB Project Grant No. SR/FT/LS-165/2012 and financial assistant from University Grant Commission (UGC), New Delhi to Mr. Buddhadeb Roy, Senior Research Fellow (Rajiv Gandhi National Fellowship) in the form of fellowship is greatly acknowledged.

\section{References}

Aswatha Narayana, D.S., K.S. Rangaswamy, M.N. Shankarappa, M.N. Maruthi, C.N.L. Reddy, A.R. Rekha, Murthy, K.V.K. 2007. Distinct Begmoviruses closely related to cassava mosaic viruses causes Indian Jatropha Mosaic Disease. Int. J. Virol., 3: 1-11.

Chakraborty, S., A.K. Pandey, M.K. Banerjee, G. Kalloo, and Fauquet, C.M. 
2003. Tomato leaf curl Gujarat virus, a new Begomovirus species causing severe leaf curl disease of tomato in Varanasi. India. Phytopathol., 93: 1485149.

Ghosh, R., S. Paul, S.K. Ghosh, Roy, A. 2009. An improved method of DNA isolation suitable for PCR based detection of begomoviruses from jute and other mucilaginous plants. J. Virol. Methods, 159: 34-39.

Heller, J. 1992. Studies on genotypic characteristics and propagation and cultivation methods for physic (Jatropha curcus L.) Dr. Kovac, Hamburg.

Openshaw, K. 2000. A review of Jatropha curcas: an oil plant of unfulfilled promise. Biomass Bioenerg., 19: 1-15.

Pramanik, K. 2003. Properties and use of Jatropha curcas oil and diesel fuel blends in compression ignition engine. Renew. Energy, 28: 239-248.

Raj, S.K., S.K. Snehi, S. Kumar, M.S. Khan, Pathre, U. 2008. First molecular identification of a begomovirus in India that is closely related to Cassava mosaic virus and causes mosaic and stunting of Jatropha curcas L. Australas. Plant Dis. Notes, 3: 69-71.

Roy, B., B. Chakraborty, A. Mitra, S. Sultana,
Sherpa, A.R. 2015. Natural occurrence of Bhendi yellow vein mosaic virus on Litsea spp. in India. New Dis. Rep., 31: 7.

Sharma, S.K., Singh, H. 2013. Pharmacognostical standardisation of Jatropha integerrima Jacq. (Euphorbiaceae) roots. Der Pharmacia Lettre., 5: 155-159.

Singh, R., S.K. Raj, Prasad, V. 2008. Molecular characterization of a strain of Squash leaf curl China virus from North India. J. Phytopathol., 156: 222-228

Snehi, S.K., M.S. Khan, S.K. Raj, Prasad, V. 2011. Complete nucleotide sequence of Croton yellow vein mosaic virus and DNA- $\beta$ associated with yellow vein mosaic disease of Jatropha gossypifolia in India. Virus Genes., 43: 93-101.

Speight, J.G., Singh, K. 2014. Environmental Management of Energy From Biofuels and Bio feed stocks. John Wiley \& Sons, http://dx.doi.org/10.1002/97811189151 41.

Weigel, K., J.O. Pohl, C. Wege, Jeske, H. 2015. A population genetics perspective on geminivirus infection. J. Virol., 89: 11926 -11934. doi:10.1128/JVI.0195615.

\section{How to cite this article:}

Buddhadeb Roy, Siriya Sultana and Ang Rinzing Sherpa. 2017. Molecular Characterization of a Jatropha leaf curl virus (JLCuV) Infecting a New Host Ludwigia parviflora in India. Int.J.Curr.Microbiol.App.Sci. 6(5): 103-109. doi: http://dx.doi.org/10.20546/ijcmas.2017.605.013 